\title{
PENINGKATAN HASIL BELAJAR MATEMATIKA MELALUI METODE PEMECAHAN MASALAH (SEBUAH PENELITIAN TINDAKAN)
}

\author{
Andi Muhammad Ajiegoena \\ Universitas Muhammadiyah Tangerang \\ Email: ajieguna@yahoo.co.id
}

\begin{abstract}
The objective of this research is to know learning process to increase elementary student learning outcomes in math study through problem solving method. The research also to find out the changing of learning outcomes after acting method. About twenty one students of SDN 22 Belopa the subject of this research. The research uses action research method by Kemmis and Mc. Taggart which consist of four steps: (a) planning, (b) action, (c) observation, and (d) reflection. The data collecting techniques use field notes, documentations, and observation. This research also uses quantitative and qualitative analyses. The result of the research indicate that learning outcomes of math were improvements with using problem solving method after acting in learnig. The significant improvement was proved with the test of relsulting student from $66.6 \%$ at the first cycle, and raising level $80.9 \%$ the second cycle.
\end{abstract}

Keywords: Improvement, learning outcomes, problem solving methods

\begin{abstract}
Abstrak: Tujuan penelitian ini adalah untuk mengetahui proses pembelajaran untuk meningkatkan hasil belajar siswa SD dalam bidang studi Matematika melalui metode pemecahan masalah. Penelitian ini juga untuk mengetahui perubahan hasil belajar setelah dilakukan tindakan. Subjek Penelitian ini terdiri dari duapuluh satu siswa SDN 22 Belopa. Penelitian ini menggunakan metode penelitian tindakan oleh Kemmis dan Mc. Taggart yang terdiri dari empat langkah: (a) perencanaan, (b) tindakan, (c) observasi, dan (d) refleksi. Teknik pengumpulan data menggunakan catatan lapangan, dokumentasi, dan observasi. Penelitian ini juga menggunakan analisis kuantitatif dan kualitatif. Hasil penelitian menunjukkan bahwa hasil belajar Matematika dapat mengalami peningkatan dengan menggunakan metode pemecahan masalah. Peningkatan yang signifikan terbukti dengan hasil tes siswa dari $66,6 \%$ pada siklus pertama, dan meningkat $80,9 \%$ pada siklus kedua.
\end{abstract}

Kata Kunci: Peningkatan, hasil belajar, metode pemecahan masalah

\section{Pendahuluan}

Dewasa ini pendidikan menjadi hal yang penting demi keberlangsungan hidup seorang individu. Persaingan yang pesat di era globalisasi menjadikan seorang individu tidak bisa bersantai jika ingin meraih masa depan yang lebih baik dan memiliki derajat yang dihargai. Pendidikan yang sangat penting yang harus diberikan sejak dini salah satunya adalah pendidikan Matematika.

Tujuan pengajaran Mata Pelajaran Matematika di Sekolah Dasar, mencakup aspek holistik siswa. Tujuan untuk aspek kognitif adalah pemahaman konsep dan penggunaan penalaran, tujuan aspek keterampilan adalah memecahkan masalah dan mengkomunikasikan gagasan, serta tujuan aspek afektif adalah memiliki sifat menghargai kegunaan Matematika.

Tujuan pembelajaran Matematika sebagai sebuah tujuan kurikuler tentunya sejalan dengan tujuan pendidikan nasional yakni mencerdaskan kehidupan bangsa dan mengembangkan manusia Indonesia seutuhnya. Pembelajaran Matematika diharapkan mampu mencetak manusia unggul yang memiliki kemampuan berfikir kritis, analitik dan rasional sebagai modal dasar penguasaan teknologi di era globalisasi. 
Matematika adalah salah satu ilmu dasar (Basic Science) yang cukup berkembang pesat saat ini. Sebagai ilmu dasar, Matematika berfungsi sebagai sumber dari ilmu-ilmu yang lain. Banyak teori dan cabang dari disiplin ilmu lainnya dikembangkan melalui pendekatan konsep Matematika. Dengan kata lain, perkembangan Matematika tidak hanya berlaku secara internal untuk dirinya sendiri sebagai suatu ilmu tetapi juga berlaku secara eksternal yakni melayani ilmu pengetahuan dalam pengembangan dan operasionalnya.

Matematika merupakan ilmu yang terstruktur yang mempelajari pola keteraturan dan tentang struktur yang terorganisasikan. Struktur Matematika dimulai dari unsur-unsur yang tidak terdefinisikan, kemudian kepada unsur yang didefinisikan, ke aksioma/postulat dan akhirnya pada teorema. Konsep-konsep Matematika tersusun secara hierarkies, terstruktur, logis, dan sistematis mulai dari konsep yang paling sederhana sampai pada konsep yang paling kompleks.

Pandangan yang lain mendefinisikan Matematika sebagai aktivitas manusia, di mana Matematika merupakan ilmu real yang bisa diaplikasikan secara langsung dalam kehidupan sehari-hari. Tanpa disadari, ilmu Matematika sering kita terapkan untuk menyelesaikan setiap masalah kehidupan. Karena itu, Matematika merupakan ilmu yang benar-benar menyatu dalam kehidupan sehari-hari dan mutlak dibutuhkan oleh setiap manusia, baik untuk dirinya sendiri maupun untuk berinteraksi dengan sesama manusia.

Dewasa ini terjadi pergeseran pandangan terhadap Matematika, dari pandangan yang semula memandang Matematika sebagai ilmu pengetahuan yang ketat dan terstruktur secara rapi ke pandangan bahwa Matematika adalah aktivitas kehidupan manusia. $\mathrm{Hal}$ ini berpengaruh terhadap cara memperolehnya, yaitu dari penyampaian rumus-rumus, definisi, aturan, hukum, konsep, prosedur, dan algoritma menjadi penyampaian konsep-konsep
Matematika melalui konteks yang bermakna dan yang berguna bagi siswa. Matematika yang bermakna apabila topiknya berkaitan dengan kehidupan sehari-hari siswa, kebutuhan dan ketertarikan mereka, serta ketika siswa terlibat aktif dalam menemukan, memahami, dan mengaitkan pengetahuan mereka.

Matematika merupakan salah satu mata pelajaran yang mendapatkan perhatian lebih di sekolah, hal ini dapat dilihat pada struktur dan alokasi waktu yang disediakan dalam kurikulum Sekolah Dasar saat ini, dibandingkan dengan beberapa mata pelajaran yang lainnya. Dalam dunia pendidikan dasar di Indonesia, Matematika merupakan salah satu mata pelajaran yang menentukan kelulusan bagi siswa. Selain sebagai salah satu mata pelajaran penentu kelulusan, Matematika juga mengajarkan siswa untuk menjadi individu yang mandiri. Sehingga siswa dapat berpikir ilmiah dan logis, serta dapat memecahkan masalah sehari-hari yang dihadapinya. Penguasaan Kompetensi Matematika dalam hal pemecahan masalah termaktub jelas dalam Peraturan Menteri Pendidikan Nasional No. 22 tahun 2006 urutan ketiga, yaitu peserta didik memiliki kemampuan memecahkan masalah, merancang model dan menafsirkan solusi. Selain itu, urgensi kompetensi pemecahan masalah juga terlihat jelas dalam tujuan pengajaran mata pelajaran Matematika di Sekolah Dasar menurut Kurikulum Tingkat Satuan Pendidikan (KTSP).

Adapun tujuan pengajaran Mata Pelajaran Matematika di Sekolah Dasar, menurut Kurikulum Tingkat Satuan Pendidikan (KTSP) yaitu agar peserta didik memiliki kemampuan sebagai berikut: (1) memahami konsep Matematika, menjelaskan keterkaitan antar konsep dan mengaplikasikan konsep atau algoritma, secara luas, akurat, efisien, dan tepat dalam pemecahan masalah, (2) menggunakan penalaran pada pola dan sifat, melakukan manipulasi Matematika dalam membuat generalisasi, menyusun bukti, atau menjelaskan gagasan dan pernyataan Matematika, 
(3) memecahkan masalah yang meliputi kemampuan memahami masalah, merancang model Matematika, menyelesaikan model dan menafsirkan solusi yang diperoleh, (4) mengkomunikasikan gagasan dengan simbol, tabel, diagram, atau media lain untuk memperjelas keadaan atau masalah, (5) memiliki sifat menghargai kegunaan Matematika dalam kehidupan, yaitu memiliki rasa ingin tahu, perhatian, dan minat dalam mempelajari Matematika, serta sikap ulet dan percaya diri dalam pemecahan masalah.

Dari uraian di atas terlihat jelas kedudukan pemecahan masalah dalam komposisi pembelajaran metematika secara nasional. Maka tuntutan penguasaan kompetensi pemecahan masalah sebenarnya bukan hanya menjadi domain dari peserta didik sebagai subjek utama proses pendidikan, akan tetapi tentunya juga menjadi domain dari para guru yang mengajarkannya. Guru dituntut memiliki kompetensi pemecahan masalah dan mampu untuk mengajarkan konsep pemecahan masalah melalui model pembelajaran pemecahan masalah Matematika.

Seorang guru dalam memberikan atau mengajari Matematika dituntut untuk memenuhi beberapa aspek, yaitu latar belakang pendidikan, penguasaan materi, dan teknik penyampaian meteri. Dengan kata lain, seorang guru harus memiliki pemahaman yang tepat terhadap ilmu Matematika. Guru harus memahami secara luas dan mendalam sekaligus menguasai teknik penyampaian agar Matematika mudah diterima oleh siswa.

Pada kenyataannya, pembelajaran Matematika masih jauh dari apa yang kita harapkan baik secara makro maupun mikro proses. Secara makro proses maksudnya berkaitan dengan skala yang luas yakni pencapaian pembelajaran Matematika secara nasional sedangkan mikro proses berkaitan dengan skala yang lebih sempit yakni proses pembelajaran Matematika di kelas.
Secara makro proses terjadi penurunan hasil tes penguasaan Sains dan Matematika siswa Indonesia. Berdasarkan hasil Trends in International Mathematics and Science Study yang diikuti siswa kelas VIII Indonesia tahun 2011, prestasi Sains dan Matematika Indonesia menurun, untuk bidang Matematika Indonesia berada di urutan ke-38 dengan skor 386 dari 42 negara. Skor Indonesia ini turun 11 poin dari penilaian tahun 2007. Penurunan hasil tes ini perlu dicermati serius oleh semua pihak yang terkait. Pembelajaran Sains dan Matematika mendesak untuk diubah agar siswa memiliki keunggulan daya nalar dan kemampuan memecahkan masalah secara ilmiah.

Secara mikro proses Matematika merupakan mata pelajaran yang kurang diminati oleh siswa Sekolah Dasar. Bagi siswa, Matematika merupakan pelajaran yang dianggap paling sulit karena untuk memahami materinya pun dianggap sebagai pekerjaan yang berat. Selama ini proses pembelajaran Matematika di sekolah dasar juga tidak memperlihatkan perubahan yang sangat signifikan sehingga tidak dapat merubah paradigma Matematika sebagai mata pelajaran yang sulit. Terutama dalam penyelesaian soalsoal yang membutuhkan pemecahan masalah serta penalaran yang tinggi. Perkembangan pola pikir, penggunaan logika, dan perhitungan yang berbasis angka desimal ternyata membuat Matematika menjadi ilmu yang abstrak, dilain sisi tahap perkembangan pemikiran anak masih berada pada tahap operasional kongkrit yang kecenderungan berfikirnya melalui hal yang kongkrit.

Persepsi negatif siswa terhadap Matematika tidak hanya berasal dari faktor keilmuan Matematika tetapi juga dipengaruhi oleh beberapa faktor dari luar. Faktor dari luar yang dianggap mempengaruhi kondisi tersebut adalah proses pembelajaran yang kurang bermakna bagi siswa. Metode pembelajaran secara langsung akan mempengaruhi persepsi siswa, metode pembelajaran yang sesuai dengan perkembangan anak serta sesuai dengan konsep Matematika 
akan mempermudah proses belajar dalam diri anak.

Penggunaan metode atau pendekatan pembelajaran oleh guru juga dirasakan kurang bervariasi, sehingga dalam proses belajar mengajar, guru cenderung lebih aktif daripada siswa. Hal ini disebabkan oleh kurangnya keterampilan yang dimiliki guru dalam menggunakan metode atau pendekatan yang tepat pada saat pembelajaran sehingga membuat anak menjadi pasif, dimana hanya guru yang mendominasi.

Pada fase pratindakan, peneliti melakukan observasi dalam upaya mengidentifikasi masalah. Observasi yang dilakukan peneliti menyangkut proses pembelajaran Matematika di kelas V SDN No. 22 Kota Belopa. Dari hasil observasi terlihat bahwa guru masih bertindak sebagai pusat pembelajaran. Guru senantiasa menjadi pusat perhatian dengan mendemonstrasikan Matematika yang sudah siap saji dengan cara penyelesaian contoh soal. Siswa kemudian dituntut untuk menguasai dengan baik cara penyelesaian soal tersebut dengan latihan mengerjakan soal. Yang menjadi permasalahan adalah siswa mampu menyelesaikan soal pada konteks dan kondisi yang diajarkan, tetapi pada konsep yang sama untuk konteks dan kondisi yang berbeda, siswa menyerah dan tidak dapat melakukan proses penyelesaian Matematika. Permasalahan di atas juga terjadi dikarenakan kurangnya kreativitas guru dalam mengemas situasi pembelajaran, guru terkesan mengajar dengan metode yang monoton tanpa melibatkan partisipasi aktif siswa.

Pada prapenelitian terungkap data rendahnya hasil belajar siswa dimana dari 21 siswa kelas $\mathrm{V}$ tersebut hanya 9 orang siswa yang mencapai Kriteria Ketuntasan Minimal (KKM) dengan distribusi tiga orang mendapatkan nilai 85 , tiga orang mendapatkan nilai 80 , satu orang mendapatkan nilai 75 , dan dua orang mendapatkan 70. Dengan demikian ketuntasan belajar $42,8 \%$. Sedangkan sekitar $57,2 \%$ atau lebih dari setengah siswa pada kelas itu memiliki nilai di bawah KKM yang telah ditetapkan yakni 70 untuk mata pelajaran Matematika kelas V SD. Secara keseluruhan nilai rata-rata kelas sebesar 65,7. Jika masalah tersebut dibiarkan berlarut-larut maka akan berdampak buruk bagi kemajuan belajar siswa terhadap materi-materi pembelajaran selanjutnya. Di ketahui penyajian materi Matematika dalam kurikulum bersifat integratif dan berkesinambungan yakni bergerak dari hal sederhana menuju penerapan yang lebih kompleks, sehingga perbaikan mutu pembelajaran mutlak dilakukan agar pemahaman siswa dapat sejalan dengan materi pembelajaran.

Pembelajaran pemecahan masalah secara optimal ternyata tidak hanya faktor guru saja, tetapi faktor tuntutan kurikulum yang membuat guru terdesak dengan waktu yang terbatas dalam kalender pendidikan membuat guru tidak fokus terhadap kemampuan pemecahan masalah.

Di kelas V Sekolah Dasar mata pelajaran Matematika mendapat alokasi waktu 6 (enam) jam pelajaran tiap minggunya, ini merupakan alokasi waktu yang cukup banyak dibandingkan mata pelajaran yang lain. Namun demikian tingkat penguasaan materi pelajaran Matematika rata-rata masih rendah. Sehingga hasil belajar Matematika juga rendah, apalagi materi di kelas V Sekolah Dasar banyak yang berkaitan dengan soal-soal pemecahan masalah.

Pendekatan pemecahan masalah adalah teknik untuk membantu siswa agar memahami dan menguasai materi pembelajaran dengan menggunakan strategi pemecahan masalah. Dalam pembelajaran Matematika, pembelajaran dengan pendekatan pemecahan masalah berarti guru menyajikan materi pelajaran dengan mengarahkan siswa kepada pemanfaatan strategi pemecahan masalah dalam memahami materi pelajaran dan dalam menyelesaikan soal-soalnya. Materi pelajaran dipandang sebagai sekumpulan masalah yang harus dipahami dan diselesaikan. Dengan pemecahan masalah diduga potensi intelektual siswa meningkat, kepuasan siswa akan timbul dari dalam dirinya, dan proses pengendapan materi Matematika yang dipelajari 
siswa akan tahan lebih lama. Hal inilah yang melatarbelakangi peneliti merasa perlu mengkaji penggunaan metode pemecahan masalah pada mata pelajaran Matematika di Sekolah Dasar.

Berdasarkan latar belakang masalah yang dikemukakan di awal, maka fokus penelitian ini adalah proses pembelajaran Matematika di kelas V SD dengan metode pemecahan masalah. Rumusan pertanyaan penelitian adalah sebagai berikut: "Bagaimanakah meningkatkan hasil belajar Matematika siswa kelas V SD melalui metode pemecahan masalah? ”.

\section{Landasan Teori}

Penggunaan penelitian tindakan bertujuan untuk memperbaiki atau meningkatkan mutu pendidikan. Kurt Lewin dalam Stephen, merupakan orang yang pertama kali memperkenalkan action research atau penelitian tindakan. Konsep pokok penelitian tindakan model Kurt Lewin terdiri dari empat komponen yaitu perencanaan, tindakan, pengamatan, dan refleksi. 'Tindakan kelas hanyalah sebuah istilah dalam bidang pendidikan yang digunakan untuk menggambarkan perkembangan kurikulum sekolah, perkembangan gurunya dalam memperbaiki program pendidikan, dan merencanakan suatu sistem yang digunakan untuk mengambil keputusan yang terbaik. Adapun sistematikanya meliputi observasi, refleksi dan melakukan tindakan yang terintegrasi dalam seluruh kegiatan.

Model penelitian Kurt Lewin selanjutnya dikembangkan oleh Stephen Kemmis dan McTaggart dalam David Hopkins, yang mengatakan bahwa penelitian tindakan adalah sebuah bentuk inkuri reflektif yang dilakukan secara kemitraan mengenai situasi sosial tertentu (termasuk pendidikan) untuk meningkatkan rasionalitas dalam pencapaian tujuan dari: 1) kegiatan praktik sosial atau pendidikan

\footnotetext{
${ }^{1}$ Stephen Waters Adam, Action Research in Education, (New York: Guilford Press,2006), p. 67.
}

mereka, 2) pemahaman mereka mengenai kegiatan-kegiatan praktik pendidikan, 3) situasi yang memungkinkan terlaksananya kegiatan praktik. ${ }^{2}$ Maksud dari pengertian tindakan kelas di atas adalah penelitian ini hanya memfokuskan pada permasalahan yang dihadapi guru seharihari di kelas. Permasalahan-permasalahan tersebut diamati untuk dicari solusinya dengan menggunakan berbagai ilmu pengetahuan yang terkait. Permasalahan-permasalahan yang dihadapi guru mampu diselesaikan menjadi lebih baik dengan menggunakan berbagai ilmu yang relefan.

Dengan demikian penjabaran pengertian teori-teori penelitian tindakan kelas diatas dapat dirumuskan bahwa penelitian tindakan kelas adalah suatu cara yang dilakukan sekelompok guru untuk mengorganisasikan kondisi praktik pembelajaran mereka, dan belajar dari pengalaman mereka sendiri. Mereka dapat menguji cobakan suatu gagasan perbaikan dalam praktik pembelajaran mereka, dan melihat pengaruh nyata dari upaya tersebut.

Penelitian tindakan kelas mempunyai banyak model sehingga peneliti dapat memakai salah satu model yang sesuai dengan yang dikehendaki. Tujuan utama model tindakan ini menurut Hopkins yaitu: (1) memberikan overview yang memadai tentang penelitian tindakan untuk membantu memperoleh pemahaman tentang keseluruhan prosesnya, (2) menunjukan bahwa meskipun ada banyak model yang berbeda, semuanya pada umumnya menyiratkan kesamaan.

Model penelitian Kemmis dan McTagart merupakan model penelitian yang dikembangkan dari model penelitian Kurt Lewin, hanya saja komponen acting dan observing dijadikan satu kesatuan karena keduanya merupakan tindakan yang tidak terpisahkan, terjadi dalam waktu yang sama. Dalam perencanaannya, Kemmis menggunakan sistem spiral refleksi diri yang

\footnotetext{
2 David Hopkins, Panduan Guru Penelitian Tindakan Kelas (A Teacher's Guide Classroom Research), (Yogyakarta: Pustaka Belajar, 2011), h. 55
} 
dimulai dengan rencana (planning), tindakan (acting), pengamatan (observing), refleksi (reflecting), dan perencanaan kembali. Apabila satu siklus selesai diimplementasikan khususnya sesudah adanya refleksi, kemudian diikuti dengan adanya perencanaan ulang yang dilaksanakan dalam bentuk siklus tersendiri. Demikian seterusnya, atau dengan beberapa kali siklus. ${ }^{3}$

\section{Hasil Belajar Matematika}

Belajar secara umum dapat dipahami sebagai tahapan perubahan tingkah laku individu yang relatif menetap sebagai hasil pengalaman dan interaksi dengan lingkungan yang melibatkan proses kognitif. Perubahan menjadi ciri utama dari belajar, seseorang yang dikatakan telah mengalami proses belajar hanya dapat dinilai dari perubahan yang terjadi pada dirinya. Namun, konteks perubahan yang dimaksud tidak dalam arti luas tetapi terbatasi oleh sebuah definisi tersendiri. Perubahan sebagai konsekuensi dari belajar memiliki ciri relatif tetap, mengarah kearah positif dan kontinyu, fungsional dan bermanfaat sebagai bekal hidup dan terjadi pada aspek kualitas manusia, bukan pada kuantitas.

Perubahan juga menjadi bagian utama dari konsep belajar yang sebenarnya merujuk pada aspek hasil belajar. Jadi perubahan tidak hanya menjadi ciri proses belajar tetapi sekaligus menjadi ciri hasil dari belajar. Wittig dalam Muhibin, mendefinisikan belajar sebagai: any relatively permanent change in an organism's behavioral repartoire that occurs as a result of experinces. Hasil belajar dapat dijelaskan dengan memahami dua kata yang membentuknya yaitu "hasil" dan "belajar". Pengertian hasil menunjuk pada suatu perolehan akibat dilakukannya aktivitas atau proses yang mengakibatkan perubahan input secara fungsional. ${ }^{4}$

\footnotetext{
${ }^{3}$ David Hopkins, Panduan Guru Penelitian Tindakan Kelas, h. 95 .

${ }^{4}$ Muhibbin Syah, Psikologi Belajar, ( Jakarta: Rajawali Press, 2012), h.66.
}

Lebih jauh Isriani, dkk mendefinisikan hasil belajar adalah perubahan perilaku manusia akibat belajar yang disebabkan karena pencapaian penguasaan atas sejumlah bahan yang diberikan dalam proses belajar di mana hasil itu dapat berupa perubahan dalam aspek kognitif, afektif maupun psikomotor.

Sejalan dengan itu Robert M. Gagne dalam Mulyono menjelaskan konsep belajar sebagai proses, sedangkan konsep hasil belajar sebagai kapabilitas, hasil belajar didefinisikan sebagai kapabilitas yang disebabkan oleh stimulasi yang berasal dari lingkungan dan proses kognitif yang dilakukan oleh siswa, bentuk-bentuk kapabilitas sebagai hasil dari belajar yaitu informasi verbal, keterampilan intelektual, strategi kognitif, keterampilan motorik, dan sikap sebagai kemampuan dalam menerima maupun menolak suatu obyek berdasarkan penilaian. ${ }^{6}$

Di lain pihak Suprijono (dalam Thobroni) mendefinisikan hasil belajar adalah pola-pola perbuatan, nilai-nilai, pengertian-pengertian, sikap-sikap, apresiasi dan ketarampilan. Perbedaan pada pendapat ini sebenarnya hanya pada aspeknya saja, sudut pandang terhadap hasil belajar sebagai konsekuensi dari proses belajar tetap dipandang sama?

Selain itu Thobroni mendefinisikan hasil belajar sebagai perubahan perilaku secara komprehensif pada kompetensi kemanusiaan yang meliputi kecakapan, informasi, pengertian.

Menurut Liebeck yang dikutip Abdurrahman, ada dua macam hasil belajar Matematika yang harus dikuasai siswa, yakni perhitungan Matematika (mathematics Calculation) dan penalaran Matematika (Mathematics Reasonning). ${ }^{8}$ Dari pendapat

\footnotetext{
${ }^{5}$ Isriani Hardini \& Dewi Puspitasari, Strategi Pembelajaran Terpadu, (Yogyakarta: Familia, 2011), h. 175.

6 Mulyono Abdurrahman, Pendidikan Anak Berkesulitan Belajar, (Jakarta: Departemen Pendidikan dan Kebudayaan, 2003), h. 89.

7 Muhammad Thobroni \& Arif Mustofa, Belajar dan Pembelajaran, (Jogjakarta: Ar-ruzz Media, 2012), h. 22.

8 Mulyono Abdurrahman, Pendidikan Anak Berkesulitan Belajar, h. 167.
} 
tersebut dapat disimpulkan bahwa hasil belajar Matematika adalah perubahan perilaku peserta didik akibat belajar yang disebabkan karena pencapaian penguasaan atas sejumlah bahan yang diberikan dalam proses belajar di mana hasil itu dapat berupa perubahan dalam aspek kognitif, afektif maupun psikomotor.

\section{Metode Pemecahan Masalah}

Pemecahan masalah merupakan bagian dari kurikulum Matematika yang sangat penting karena dalam proses pembelajaran maupun penyelesaian, siswa dimungkinkan memperoleh pengalaman menggunakan pengetahuan serta keterampilan yang sudah dimiliki untuk diterapkan pada pemecahan masalah yang bersifat tidak rutin. Melalui kegitan ini aspekaspek kemampuan Matematika penting seperti penerapan aturan pada masalah tidak rutin, penemuan pola, penggeneralisasian, komunikasi Matematika, dan lain-lain dapat dikembangkan secara baik.

Metode pembelajaran merupakan kegiatan yang dipilih pendidik dalam proses pembelajaran yang dapat memberikan kemudahan atau fasilitas kepada peserta didik dalam menuju tercapainya tujuan yeng telah ditetapkan. Menurut Turmudi, Problem Solving atau pemecahan masalah adalah metode penyelesaian yang tidak standar dan tidak diketahui terlebih dahulu di mana siswa untuk mencari penyelesaiannya harus memanfaatkan pengetahuan dan penalarannya dalam proses untuk mengembangkan pemahaman Matematika yang baru. ${ }^{9}$ Lebih jauh menurut George Polya dalam Tahnia menyatakan bahwa pendekatan pemecahan masalah Matematika adalah strategi pembelajaran Matematika dengan mengedepankan proses penyelesaian masalah dengan empat langkah berikut: (1) memahami masalah, (2) merencanakan pemecahan masalah, (3) menyelesaikan masalah sesuai dengan

9 Turmudi, Landasan Filsafat dan Teori Pembelajaran Matematika, (Jakarta: Leuser Cita Pustaka, 2008), h.39. rencana, (4) memeriksa kembali hasil yang diperoleh. ${ }^{10}$

Pendapat senada diungkapkan oleh Roudatul yang menyatakan bahwa metode pemecahan masalah adalah suatu metode berfikir yang dimulai dengan mencari data sampai menarik kesimpulan, penggunaan metode ini mengikuti langkah-langkah: (1) adanya masalah yang jelas untuk dipecahkan, (2) mencari data atau keterangan yang dapat digunakan, (3) menetapkan jawaban sementara, (4) menguji kebenaran sementara itu, (5) menarik kesimpulan. ${ }^{11}$

Di lain pihak Rohayah berpendapat pemecahan masalah adalah suatu proses untuk menemukan kombinasi dari sejumlah aturan yang dapat diterapkan dalam upaya menerapkan situasi yang baru. ${ }^{12}$ Stephen mengemukakan enam tahap pemecahan masalah yakni: (1) identification the problem, (2) representation of the problem, (3) planning the solution, (4)execute the plan, (5) evaluate the plan, (6) evaluate the solution. ${ }^{13}$ Dari pendapat tersebut dapat disimpulkan bahwa metode pemecahan masalah merupakan metode pembelajaran yang menekankan pengetahuan dan penalaran dalam proses berpikir siswa untuk mampu menyelesaikan suatu masalah secara aplikatif melalui langkah-langkah pembelajaran sebagai berikut: (1) memahami masalah, (2) merencanakan pemecahan masalah, (3) menyelesaikan masalah sesuai dengan rencana, (4) memeriksa kembali hasil yang diperoleh.

\footnotetext{
${ }^{10}$ Ayu Tahnia., Yosef dan Masrinawatie A.S., Model Pemecahan Masalah Dalam Pembelajaran Matematika di Sekolah Dasar, (Malang: Jurnal Sekolah Dasar, Vol. 20 (2), 2011), h. 90 .

${ }^{11}$ Roudatul Jannah, Membuat Anak Cinta Matematika dan Eksak Lainnya, (Jogjakarta: Diva Press, 2011), h. 108.

${ }^{12}$ Siti Rohayah \& Erni Kurniawati, Agar Anak Senang Belajar Matematik, (Jakarta: Pustaka Zeedny, 2011), h. 256.

13 Stephen Waters Adam, Action Research in Education, p. 75 .
} 


\section{Metode Penelitian}

Penelitian ini merupakan penelitian tindakan dengan pendekatan kualitatif dan kuantitatif, penelitian tindakan ini dilaksanakan selama dua siklus, setiap siklus merupakan rangkaian kegiatan yang saling berkaitan. Artinya pelaksanaan siklus II merupakan kelanjutan dan perbaikan dari pelaksanaan tindakan siklus I. Mekanisme pelaksanaan tindakan mengikuti model Kemmis dan Taggart yakni : pada tahap awal dimulai dengan melaksanakan prapenelitian untuk memperoleh ide awal, langkah selanjutnya adalah: (1) menyusun perencanaan tindakan, (2) pelaksanaan tindakan, (3) observsi, (4) refleksi.

1. Tahap Pratindakan

Mengadakan observasi awal terhadap kondisi pembelajaran Matematika dalam upaya mengdiagnosa masalah belajar di kelas V SDN No. 22 Kota Belopa. Mengamati proses pembelajaran Matematika di dalam kelas serta melihat sejauhmana pencapaian hasil belajar siswa.

2. Perencanaan tindakan

Menyusun tindakan yang akan dilaksanakan dalam menangani masalah berdasarkan hasil observasi awal yang dihadapi yaitu rendahnya hasil belajar Matematika siswa di kelas V SD. Adapun rencana tindakan pada siklus satu yakni pada materi pokok pecahan. Standar Kompetensi: Menggunakan pecahan dalam pemecahan masalah

3. Pelaksanaan Tindakan

Tahap selanjutnya adalah melaksanakan rencana kegiatan yang telah disusun pada tahap perencanaan yakni pembelajaran Matematika melalui Metode Pemecahan Masalah. Adapun tahap pembelajarannya dengan empat langkah berikut: (1) memahami masalah, (2) merencanakan pemecahan masalah, (3) menyelesaikan masalah sesuai dengan rencana, (4) memeriksa kembali hasil yang diperoleh.

\section{Observasi}

Melihat dan merekam proses pelaksanaan metode pemecahan masalah dalam pembelajaran Matematika, menyangkut aktivitas guru dan siswa.

5. Refleksi

Menganalisis dan mengevaluasi proses penerapan metode pemecahan masalah dalam pembelajaran Matematika di kelas V SD.

Keberhasilan dalam penelitian ini meliputi dua aspek, (1) indikator keberhasilan proses yakni tentang keterlaksanaan pembelajaran Matematika dengan menggunakan Metode Pemecahan Masalah, (2) indikator hasil belajar Matematika Siswa. Teknik pengumpulan data menggunakan lembar observasi, catatan lapangan dan dokumentasi penerapan metode pemecahan masalah pada setiap intervensi tindakan serta tes hasil belajar untuk mengukur pencapaian hasil belajar siswa setiap siklusnya.

\section{Hasil Penelitian}

Deskripsi pelaksanaan pada siklus I dapat dijelaskan sebagai berikut : (1) guru menyajikan masalah berupa soal cerita non-rutin yang berkaitan dengan konsep mengubah bentuk pecahan, (2) siswa dibagi ke dalam beberapa kelompok, (3) siswa melakukan diskusi kelompok mengkaji masalah dalam upaya memahami masalah, menuliskan pola, (4) siswa mencari hubungan di antara pola masalah dan merencanakan teknik pemecahan masalahnya, (5) siswa menyelesaikan masalah sesuai dengan rencana pemecahan masalahnya, (6) siswa melakukan pengecekan dari hasil yang diperoleh. Pembelajaran melalui metode pemecahan masalah ini menitik beratkan pada penyelesaian soal cerita masalah non-rutin secara berkelompok. Penyajian masalah non-rutin diharapkan mampu meningkatkan kemampuan berpikir serta pemahaman siswa kearah yang lebih luas dan konteksnya sesuai dengan kehidupan sehari-hari. 
Karena masih adanya kekurangan pada siklus I dalam proses pembelajaran yaitu: beberapa siswa kesulitan dalam menemukan inti masalah yang dimaksud dari soal, beberapa siswa lainnya kesulitan dalam menuliskan inti masalah tersebut kedalam bentuk kalimat Matematika, beberapa anggota kelompok terlihat pasif selama kegiatan pemecahan masalah, pada beberapa pertemuan, tahap "mengecek kembali" dirasakan belum optimal dikarenakan keterbatasan waktu bagi kelompok untuk mengecek ulang pekerjaan mereka, guru terlihat kurang efektif dalam memberikan bimbingan kepada setiap kelompok, dan kurangnya pemahaman siswa terhadap setiap langkah pemecahan masalah sehingga hasil proses pembelajaran dan hasil belajar siswa belum mencapai target yang diharapkan, maka penelitian dianggap perlu untuk dilanjutkan ke siklus II dengan beberapa perbaikan.

Tindakan pada siklus II dipaparkan sebagai berikut: (1) guru menyajikan masalah berupa soal cerita non-rutin yang berkaitan dengan konsep mengubah bentuk pecahan, (2) siswa dibagi kedalam beberapa kelompok, (3) siswa melakukan diskusi kelompok mengkaji masalah dalam upaya memahami masalah, menuliskan pola, (4) siswa mencari hubungan diantara pola masalah dan merencanakan teknik pemecahan masalahnya, (5) siswa menyelesaikan masalah sesuai dengan rencana pemecahan masalahnya. (6) siswa melakukan pengecekan dari hasil yang diperoleh. Pada siklus II ini terlihat perbaikan antara lain, pembagian kelompok secara berpasangan sehingga meningkatkan keaktifan dan tanggungjawab siswa, guru aktif dalam memberikan bimbingan pada setiap tahap pemecahan masalah, manajemen waktu yang optimal oleh guru, sehingga tahap kegiatan pemecahan masalah berlangsung secara efisien, dan siswa telah mampu melaksanakan keempat tahap pemecahan masalah dengan baik dan benar.

Hasil yang didapatkan dari proses belajar mengajar menunjukkan peningkatan dimana pada akhir siklus ke dua ketuntasan belajar siswa mencapai $80,9 \%$ dengan keterlaksanaan proses pembelajaran mencapai 94,4\%. Pencapaian tersebut telah memenuhi target penelitian, dengan demikian penelitian tindakan kelas ini dianggap berhasil, sehingga tidak dilanjutkan lagi pada siklus berikutnya. Berdasarkan hasil yang ada, maka penerapan metode pemecahan masalah dapat meningkatkan hasil belajar siswa dalam mata pelajaran Matematika.

Adapun penyajian data hasil analisis proses pembelajaran dan hasil belajar siswa dapat dijelaskan lebih lanjut melalui tabel berikut:

Tabel 1: Perbandingan Persentase Keterlaksanaan Proses Pembelajaran Melalui metode Pemecahan Masalah.

\begin{tabular}{lcc}
\hline Aspek Perbandingan & Siklus I & Siklus II \\
\hline Aktivitas Guru & $77,77 \%$ & $94,44 \%$ \\
Aktivitas Siswa & $63,88 \%$ & $94,44 \%$ \\
Rata-rata Persiklus & $70,82 \%$ & $94,44 \%$ \\
\hline
\end{tabular}

Gambar 1: Grafik Keterlaksanaan Proses

Pembelajaran melalui metode Pemecahan Masalah

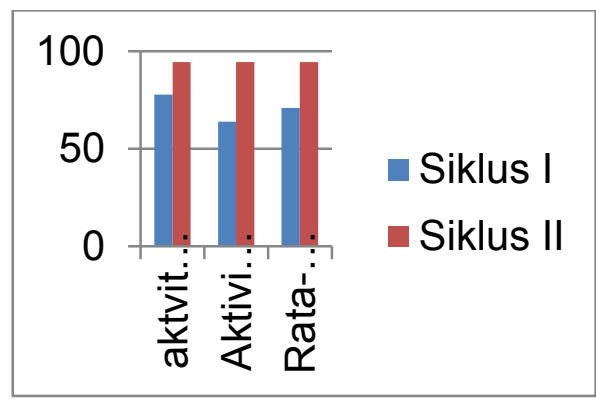

Dari tabel dan grafik di atas terlihat bahwa secara proses terjadi peningkatan keterlaksanaan proses pembelajaran melalui metode pemecahan masalah dari siklus I ke siklus II. Persentase keterlaksanaan proses pembelajaran melalui metode pemecahan masalah meningkat dari $70,82 \%$ pada siklus I menjadi 94,44\% pada siklus II. Hasil ini didapatkan dari peningkatan persentase aktivitas mengajar guru dari 77,77\% pada siklus I menjadi $94,44 \%$ pada siklus II serta aktivitas belajar siswa dari $63,88 \%$ pada siklus I menjadi 94,44\% pada siklus II.

Tabel 2: Perbandingan Hasil Belajar Siswa

\begin{tabular}{lcc}
\hline \multicolumn{1}{c}{ Aspek Perbandingan } & Siklus I & Siklus II \\
\hline Nilai Rata-rata Hasil Belajar & 70,95 & 75,23 \\
Ketuntasan Belajar & $66,6 \%$ & $80,9 \%$ \\
\hline
\end{tabular}


Gambar 2: Grafik Hasil Belajar Siswa

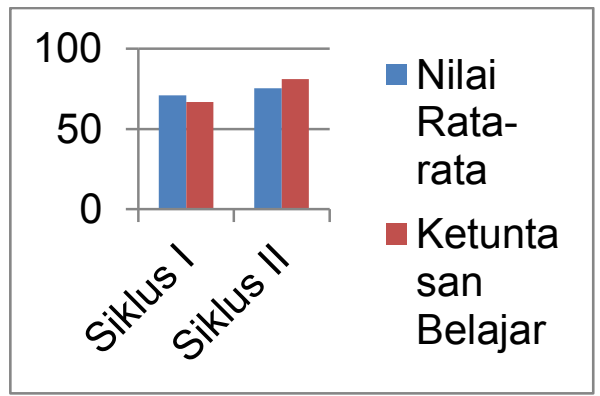

Dari tabel dan grafik diatas terlihat bahwa terjadi peningkatan hasil belajar siswa yang diukur melalui persentase ketuntasan belajar siswa. Persentase ketuntasan belajar didapatkan dari persentase jumlah siswa yang memenuhi target KKM yang ditetapkan sekolah yakni 70 untuk mata pelajaran Matematika kelas V. Ketuntasan belajar siswa meningkat dari 66,6\% pada siklus I menjadi 80,9 \% pada siklus II dengan nilai rata-rata hasil belajar siswa juga ikut meningkat dari 70,95 pada siklus I menjadi 75,23 pada akhir siklus II.

\section{Penutup}

Berdasarkan temuan dan pembahasan hasil penelitian ini, kesimpulan yang dapat diambil adalah pembelajaran dengan menggunakan metode pemecahan masalah dapat meningkatkan kemampuan berpikir kritis dan kreatif siswa serta meningkatkan pemahaman konsep Matematika siswa ke arah yang lebih luas, sehingga mereka dapat menerapkannya dalam menyelesaikan masalah sehari-hari. Sehingga, pembelajaran Matematika melalui penerapan metode pemecahan masalah mampu meningkatkan keaktifan serta minat siswa terhadap pembelajaran Matematika. Sejalan dengan itu, terjadi peningkatan hasil belajar siswa setelah penerapan metode pemecahan masalah dalam pembelajaran, hal ini dibuktikan dari perhitungan ketuntasan belajar siswa dari $42,8 \%$ pada tahap pratindakan, meningkat menjadi 66,6 \% pada siklus I dan mencapai target $80,9 \%$ pada siklus II. Dan terjadi peningkatan keterlaksanaan proses pembelajaran melalui penerapan metode pemecahan masalah dari $70,82 \%$ pada siklus I menjadi $94,44 \%$ pada siklus II.

Untuk itu, disarankan agar metode pemecahan masalah sebagai alternatif dalam pembelajaran Matematika di tingkat Sekolah Dasar. Karena itu, guru sebaiknya memberikan penyajian soal Matematika berupa soal pemecahan masalah non-rutin, agar kemampuan berpikir dan pemahaman siswa meningkat. Dan lembaga pendidikan ataupun tenaga pendidik yang lulusannya menghasilkan tenaga guru Sekolah Dasar hendaknya selalu mengikuti perkembangan dalam dunia pendidikan, misalnya dengan menerapkan metode pemecahan masalah.

\section{Daftar Pustaka}

Adam, Stephen Waters, Action Research in Education, New York : Guildford Press, 2006.

Ayu, Tahnia, Yosef \& Masrinawatie A. S., Model Pemecahan Masalah Dalam Pembelajaran Matematika di Sekolah Dasar, Malang: Jurnal Sekolah Dasar, Vol. 20 (2), 2011.

David, Hopkins, Panduan Guru Penelitian Tindakan Kelas (A Teacher's Guide Classroom Research), Yogyakarta: Pustaka Belajar, 2011.

Isriani, Hardini \& Dewi Puspitasari, Strategi Pembelajaran Terpadu. Yogyakarta: Familia, 2011.

Jannah, Raoudatul, Membuat Anak Cinta Matematika dan Eksak Lainnya, Jogjakarta: Diva Press, 2011.

Muhibbin, Syah, Psikologi Belajar. Jakarta: Rajawali Press, 2012.

Mulyono, Abdurrahman, Pendidikan Anak Berkesulitan Belajar, Jakarta: Departemen Pendidikan dan Kebudayaan, 2003.

Rohayah, Siti \& Erni Kurniawati. Agar Anak Senang Belajar Matematik. Jakarta: Pustaka Zeedny, 2011. 
Peningkatan Hasil Belajar Matematika...(Andi Muhammad) 93

Suryosubroto, Proses Belajar Mengajar di Turmudi, Landasan Filsafat dan Teori Sekolah, Jakarta: Rineka Cipta, 2009.

Thobroni, Muhammad \& Arif Mustofa, Belajar Pembelajaran Matematika, Jakarta: Leuser Cita Pustaka, 2008. dan Pembelajaran. Jogjakarta: Ar-ruzz Media, 2012. 
94 | TARBIYA | Vol. I, No.1, Juni 2014 